PROFESSOR ALEJANDRO F DE NICOLA (Orcid ID : 0000-0002-3523-9148)

Article type : Original Article

\title{
MINERALOCORTICOID RECEPTOR ASSOCIATES WITH PRO-INFLAMMATORY BIAS IN HIPPOCAMPUS OF SPONTANEOUSLY HYPERTENSIVE RATS
}

\author{
María Elvira Brocca ${ }^{a}$, Luciana Pietranera ${ }^{\text {a,b }}$, Maria Meyer ${ }^{\text {a }}$, Analia Lima ${ }^{\text {, }}$, Paulina \\ Roig $^{\text {a }}$, E. Ronald de Kloet ${ }^{c}$, Alejandro F. De Nicola ${ }^{\text {a,b }}$
}

${ }^{a}$ Laboratory of Neuroendocrine Biochemistry, Instituto de Biologia y Medicina ExperimentalCONICET, Buenos Aires, Argentina.

${ }^{b}$ Dept. of Human Biochemistry, Faculty of Medicine, University of Buenos Aires, Buenos Aires, Argentina.

${ }^{c}$ Division of Endocrinology, Dept. of Internal Medicine, Leiden University Medical Center, Leiden, The Netherlands.

Short title: Mineralocorticoid receptor and neuroinflammation in hypertension.

Key words: mineralocorticoid receptor; hypertension; hippocampus; microglia; neuroinflammation.

Correspondence to: Dr. Alejandro F. De Nicola, Laboratory of Neuroendocrine Biochemistry, Instituto de Biologia y Medicina Experimental, Obligado 2490, 1428 Buenos Aires, Argentina. Email: alejandrodenicola@gmail.com. Phone: +54.11.47832869; Fax: +54.7862564 .

This article has been accepted for publication and undergone full peer review but has not been through the copyediting, typesetting, pagination and proofreading process, which may lead to differences between this version and the Version of Record. Please cite this article as doi: $10.1111 /$ jne. 12489

This article is protected by copyright. All rights reserved. 


\section{ABSTRACT}

Damage observed in the hippocampus of the adult spontaneously hypertensive rat (SHR) resembles the neuropathology of mineralocorticoid-induced hypertension, supporting a similar endocrine dysfunction in both entities. In this study we have tested the hypothesis that increased expression of the hippocampal mineralocorticoid receptor (MR) in SHR animals is associated with a prevalent expression of pro-inflammatory over anti-inflammatory factors. For this purpose we measured in hippocampus mRNA expression and immunoreactivity of the MR and the glucocorticoid receptor (GR) using QPCR and histochemistry. We also measured the serum-glucocorticoid-activated kinase 1 (Sgk1 mRNA), the number and phenotype of lba1+ microglia, mRNA expression levels of the proinflammatory factors cyclooxygenase 2 (Cox2), NIrp3 inflammasome and tumor necrosis factor alpha $(\operatorname{Tnf} \alpha)$. The expression of anti-inflammatory Tgf $\beta$ mRNA and the NADPHdiaphorase activity of nitric oxide synthase (NOS) was also determined. The results showed that in the hippocampus of SHR rats the expression of MR and the number of immunoreactive MR / GR co-expressing cells is increased as compared to the Wistar Kyoto control animals. The expression of Sgk1, Cox2, NIrp3 and the number of ramified glia cells positive for Iba1+ is increased, while Tgf $\beta$ mRNA expression and the NADPH-diaphorase activity of NOS are decreased. We propose that in the SHR hippocampus increased MR expression causes a bias towards a pro-inflammatory phenotype characteristic for hypertensive encephalopathy.

\section{INTRODUCTION}

Previous research has indicated that brain damage of the adult spontaneous hypertensive rat (SHR) resembles the neuropathology of mineralocorticoid-induced hypertension, suggesting a similar endocrine dysfunction in both situations $(1,2)$. The endocrine abnormalities of SHR include a hyperactive hypothalamus-pituitary-adrenal axis (HPA), stimulation of the brain angiotensine- and vasopressine systems and increased binding capacity and expression of the mineralocorticoid receptor (MR or NR3C2) in hippocampus and hypothalamus (3-8). Augmented MR expression has also been detected in the heart, vascular endothelial cells and kidney of SHR suggesting that increased MR function is a generalised property of this genetically selected rat strain $(9,10)$. Functional 
evidence for the implication of brain MR in hypertension comes from the enhanced expression of vasopressin and c-FOS in the hypothalamus following mineralocorticoid treatment of SHR rather than the parent strain Wistar Kyoto from which SHR were derived (1). Furthermore, a decrease of systolic blood pressure occurs after intracerebroventricular (icv) administration of the MR antagonist RU28318 (6), particularly if the SHR rats were sensitized by sodium loading (11).

In the hippocampus of SHR several alterations characteristic for damage occur, such as myelin loss, reactive astroglia and microglia, increased oxidative stress, decreased neurogenesis, neuroinflammation, vascular remodelling, neuronal mitochondrial dysfunction, decreased activity of nitric oxide synthase (NOS) and pyramidal neuron atrophy $(2,12-16)$. MR activation in brain endothelia induces mRNA of proinflammatory cytokines (17), and stimulates proliferation of the forebrain microglia (18). The resulting neuroinflammation is a strong contributor to the pathogenic effects of hypertension (19). Thus, while MR is neuroprotective to the effects of chronic stress in hippocampus $(20,21)$, it appears that during hypertension MR activation contributes to end-organ damage, which is further aggravated by salt loading (2).

The objective of the current study was to investigate if changes in the expression of the MR and its colocalised glucocorticoid receptor (GR or NR3C1) $(22,23)$ associate with the immunophenotype of microglia and neuroinflammation markers in the hippocampus of SHR. For this purpose, we used 10 month-old male SHR and WKY rats to study (1) the expression of MR and GR in hippocampus; (2) expression of the MR and GR-target gene serumglucocorticoid-activated kinase 1 (Sgk1 mRNA) as an indicator of receptor functionality (24); (3) the number and phenotype of Iba1+ microglia; (4) mRNA expression levels of the proinflammatory factors cyclooxygenase 2 (Cox2), NIrp3 inflammasome and tumor necrosis factor alpha (Tnf $\alpha)$; (5) expression of $\operatorname{Tgf} \beta$ mRNA, a factor endowed with anti-inflammatory properties (25); and (7) changes of the NADPH-diaphorase activity of nitric oxide synthase (NOS), an enzyme related to vasodilation, which is suppressed by MR activation (26). The results highlight an association between $M R$, neuroinflammation and hypertensive encephalopathy.

This article is protected by copyright. All rights reserved. 


\section{MATERIALS AND METHODS}

\section{Experimental animals}

Ten-month-old male SHR and WKY rats were purchased from the Instituto de Biologia y Medicina Experimental's animal facility. Rats were maintained under a 12:12 h light/dark cycle (lights on $7.00 \mathrm{am}$ ), controlled humidity and temperature $\left(22^{\circ} \mathrm{C}\right)$ and given food and water ad libitum. The blood pressure response, employing a tail-cuff method, measured $187.1 \pm 5.2 \mathrm{mmHg}$ in SHR and $111.8 \pm 3.0 \mathrm{mmHg}$ in control WKY rats. For immunohistochemistry (IHC) and immunofluorescence (IF) assays, rats were anesthetised with isoflurane under a fume hood, and perfused via the heart with $0.9 \% \mathrm{NaCl}$ in $0.1 \mathrm{M}$ phosphate buffer pH 7.4 (PBS) followed by 4\% paraformaldehyde (PFA, Merck, Darmstatd, Germany) in phosphate buffer at $\mathrm{pH}$ 7.4. For real time PCR, anesthetized rats were decapitated and brains collected for further analysis. Animal handling followed the Guide for the Care and Use of Laboratory Animals (NIH Guide, Instituto de Biologia y Medicina Experimental Animal Facility Assurance Certificate \# N-A5072-01) and was approved by the Institute's Animal Care and Use Committee (IACUC). Efforts were made to reduce the number of animals in the different experiments.

\section{IHC and IF assays}

After perfusion, brains were post-fixed for $24 \mathrm{~h}$ in $4 \%$ PFA at $4^{\circ} \mathrm{C}$ and transferred to $0.1 \mathrm{M}$ phosphate buffer ( $\mathrm{pH} 7.4$ ) for 2 hours. Using a vibrating microtome, $50 \mu \mathrm{m}$ coronal sections from plates 27 to 33 of the rat atlas (27) were cut and processed for free-floating IHC or IF. For IHC, endogenous peroxidase activity was quenched for 20 min in $50 \%$ methanol / $1 \%$ hydrogen peroxide in PBS. Sections were washed 3 times in PBS, blocked with $3.5 \%$ bovine serum albumin (BSA, Sigma) in PBS $-0.1 \%$ Triton X100 for lba1 staining, or treated with $10 \%$ horse serum in PBS- $0.15 \%$ Triton $\mathrm{X} 100$ for MR and $10 \%$ goat serum in PBS for GR during $30 \mathrm{~min}$ at room temperature. Afterwards, sections were incubated with primary antibodies against the MR, GR or Iba- 1 antigens. Table 1 shows the dilutions, incubation time and antibody sources used for IHC. After two overnight incubation with the respective primary antibody at $4^{\circ} \mathrm{C}$, sections were exposed to biotinylated horse anti-mouse immunoglobulin $\mathrm{G}$ or goat anti-rabbit immunoglobulin $\mathrm{G}$ and further processed in accordance with the $A B C$ kit manufacturer's instructions (Vectastain $A B C$ kit; Vector Laboratories).

This article is protected by copyright. All rights reserved. 
Immunoreactions were visualised by means of peroxidase activity using diaminobenzidine tetrachloride (DAB, $0.25 \mathrm{mg} / \mathrm{ml}$, SIGMA, St. Louis, MO) as substrate in the presence of $0.01 \%$ hydrogen peroxide for $7 \mathrm{~min}$ in the dark. The sections were given a final rinse in PBS, placed onto gelatine coated glass slides, dehydrated in a series of ethanol and xylene, and finally mounted using synthetic Canada balsam (Biopack, Buenos Aires, Argentina).

For dual IF of MR and GR, brain slices were pre-incubated with $5 \%$ goat serum in PBS$0.15 \%$ Triton $\mathrm{X} 100$ for $30 \mathrm{~min}$ at $37^{\circ} \mathrm{C}$, and then incubated with primary antibodies (Table 1) prepared in 5\% goat serum, $0.3 \%$ Triton X100 in PBS for $48 \mathrm{~h}$. Following incubation, sections were washed with PBS and incubated for $1 \mathrm{~h}$ at room temperature with a goat antirabbit IgG conjugated to Alexa Red 555 and anti- mouse IgG conjugated to Alexa 488. After further washings, sections were placed in gelatine coated glass slides and cover slipped with Fluoromont-G. If primary antibodies were omitted, immunofluorescence was negative for MR or GR. Experimental groups were stained simultaneously to eliminate inter-experiment variations and conditions were kept rigorously identical throughout the assays. In order to rule out experimental bias, the researcher was blind regarding the source of the materials.

\section{RNA purification and real-time PCR of MR, GR and proinflammatory mediators}

Immediately after killing bilateral hippocampi were removed from the brains of SHR and WKY rats, frozen on dry ice and temporarily stored at $-80^{\circ} \mathrm{C}$ until subsequent RNA purification. Tissues were homogenized with a Polytron homogenizer and total RNA was then extracted using Trizol reagent (Life Technologies-Invitrogen, CA, USA), precipitated with isopropanol and dissolved in distilled water. The concentration of total RNA was determined by measuring the OD at 260 and $280 \mathrm{~nm}$ using a nanodrop. Total RNA was subjected to Dnase 1 (Life Technologies-Invitrogen) treatment $(2 \cup$ for $10 \mathrm{~min}$ at room temperature $(\mathrm{RT})$ to remove residual contaminating genomic DNA. cDNA templates for PCR amplification were synthesized from $2 \mu \mathrm{g}$ of total RNA using a SuperScript III Rnase $\mathrm{H}$ Reverse transcriptase kit (Life Technologies-Invitrogen) for $60 \mathrm{~min}$ at $50{ }^{\circ} \mathrm{C}$ in the presence of random hexamer primers. The sequence of primers for amplification in whole hippocampus of rat MR, GR, Sgk1, Tnfa, NIrp3, Cox2 and Tgf $\beta$ is shown in Table 2. Cyclophilin $A$ was chosen as a housekeeping gene based on the similarity of mRNA expression across all sample templates. Primers were designed using Primer-BLAST web software (National Centre for Biotechnology Information, Bethesda, MD, USA) with default parameters. Primer specificity was also confirmed using Primer-BLAST.

This article is protected by copyright. All rights reserved. 
PCR analysis was carried out using the ABI PRISM 7500 Sequence Detection System (Applied Biosystems, Foster City, CA, USA) and Applied Biosystems StepOnePlus $^{\text {TM }}$ Real-Time PCR Systems (Applied Biosystems, Foster City, CA, USA). Gene expression was calculated using the $2^{-\Delta \Delta C T}$ method (28), and determined as fold induction compared to its respective control. PCR was performed in triplicate and data concerning amplification, running conditions, cDNA content and primer concentrations of each gene are specified in Table 2. Specificity of PCR amplification and the absence of dimers were confirmed by melting curve analysis. The accuracy of the reaction was confirmed by the linearity and efficiency of PCR amplification (7). Results were expressed as the mean \pm SEM of $n=7$ rats per group.

\section{Quantitative analysis of Iba1 immunoreactive cells}

Photographic observation and quantitative analysis of Iba+ (29) immunofluorescent microglial cells was performed in the stratum radiatum beneath the CA1 and CA3 pyramidal layers and in the hilus of the dentate gyrus. Images were taken using an Olympus $\mathrm{BH} 2$ microscope, coupled to a Panasonic GPKR222 camera at 600X. The total number of Iba1labeled cells from the three areas was measured and then a morphometric categorisation of microglial phenotypes was performed, as follows 1) cells with abundant ramified processes and small soma or 2) hypertrophic phenotype, containing large soma and shortened processes. The hypertrophic phenotype included cells with varying morphologies, including those with low processes and a round ameboid soma shape (30). The number of lba1+ cells of each microglia phenotype was quantified and expressed per unit of volume $\left(\mathrm{mm}^{3}\right)(\mathrm{n}=5-6$ rats per group).

\section{Determination of MR and GR immunoreactive area}

Images containing the dorsal hippocampus of SHR and WKY rats were acquired at the same magnification (212.5X) using a Panasonic GP-KR222 digital camera (Panasonic Corp., Osaka, Japan) connected to an Olympus BH2 microscope (Olympus, Tokyo, Japan) and image analysis software BIOSCAN OPTIMAS VI (Bioscan Inc., Edmonds, WA, USA). Immunoreactive MR and GR areas were determined for the CA3 (MR) and CA1 (MR, GR) 
hippocampal regions, applying a grey-scale threshold, considering that MR extends to all hippocampus subfields, whereas GR is poorly localised in the CA3 region (31). Digitalised images of tissue sections were processed simultaneously under identically operating conditions, such as light beam, wavelength and grey-scale threshold, throughout the experiment. The same number of sections ( $n=6$ per rat brain) were studied for each experimental group ( $n=6$ SHR or WKY rats). Results were expressed as total immunoreactive areas per $\mathrm{mm}^{2}$, a procedure proportional to the total immunoreactive cell number.

\section{Analysis of MR and GR co-expression in the hippocampus of SHR and WKY rats}

The percentage of MR positive cells (red) that co-express GR (green) were analysed by means of confocal microscopy. Confocal microphotographs (2048 x 2048 pixels) were taken with a Nikon DS-U1 camera with ACT-2U software couple to a Nikon Eclipse E800 confocal Microscope at 600X magnification. Pairs of images were collected simultaneously in the green and red channels. For image processing and image analysis the $\mathrm{NIH}$ image analysis software "Image $\mathrm{J} 1.51 \mathrm{~h}$ " was used. After applying a threshold, the total number of MR positive cells (red IF) were counted and the percentage of MR positive cells which also expressed GR (yellow in merged images) were calculated. Cells were counted in $n=6$ sections from $n=6$ animals per experimental group

\section{NADPH-diaphorase histochemistry}

This activity, based on the diaphorase property of NOS, was determined by the procedure of Vincent and Kimura (32) in 17- $\mu \mathrm{m}$ cryostat sections of the brain at the level of the dorsal hippocampus. Slices were fixed by immersion in $2 \%$ PFA in $0.1 \mathrm{M}$ phosphate buffer ( $\mathrm{pH} \mathrm{7.2)} \mathrm{for} 6 \mathrm{~min}$ at $4{ }^{\circ} \mathrm{C}$. After fixation, the sections were rinsed twice in PBS, and incubated in a solution containing $0.2 \mathrm{mg} / \mathrm{ml}$ of nitroblue tetrazolium, $2.7 \mathrm{mg} / \mathrm{ml}$ L-malic acid, $1 \mathrm{mg} / \mathrm{ml}$ of b-NADPH (all obtained from Sigma), 0.3\% Triton X-100 dissolved in $0.1 \mathrm{M}$ Tris-HCl buffer ( $\mathrm{pH}$ 7.4). After keeping the reaction in the dark for $60 \mathrm{~min}$ at $37^{\circ} \mathrm{C}$, it was stopped by two washes in PBS at room temperature. Sections were then dehydrated briefly in ethanol, air-dried and coverslipped with Permount. Brain areas containing blue formazan staining were analysed by computerized image analysis, as already published (33). Results ( $\mathrm{n}=5$ animals per group) were expressed as the NADPH-diaphorase active area (in $\mathrm{mm}^{2}$ ) in the CA1 and CA3 hippocampal regions.

This article is protected by copyright. All rights reserved. 


\section{Statistical analysis}

The Student's "t" test was used to determine significance between the two groups (SHR and WKY rats). In case variables did not follow normality criteria according to the Shapiro-Wilk test, the Mann Whitney test was applied (GraphPad Prism, version 4; GraphPad Software Inc., San Diego, CA, USA). All results are expressed as the mean \pm SEM and they were regarded significantly different at $p<0.05$.

\section{RESULTS}

1. MR, GR mRNA and MR protein expression and co-expression of MR with GR in the hippocampus of SHR and WKY rats.

Dual immunofluorescence analysis of the expression of MR / GR in whole hippocampus and the CA1 and CA3 regions revealed strain differences between SHR and WKY rats (Figure 1). Low power photomicrographs (Fig. 1A) showed MR staining widely distributed in pyramidal cell areas and gyrus dentatus from both SHR and WKY rats. Instead GR staining was low in CA3 pyramidal cell layer, as already reported (31). In the hippocampus, the signal for MR immunofluorescent protein (green colour), to a lesser extent GR (red colour) and co-expression with GR (merged, yellow) were stronger in SHR compared with WKY rats. Second, zoom imaging of CA1 (Fig. 1B) and CA3 regions (Fig. 1C) showed higher number of MR+ cells and slightly higher number of $G R+$ cells in both regions of SHR. Fig.1B and 1C (merged, yellow) showed enhanced colocalisation of MR /GR proteins in SHR compared to WKY rat. Furthermore, quantitative analysis of dual immunofluorescence staining of $\mathrm{MR} / \mathrm{GR}$ positive cells in the $\mathrm{CA} 1$ region of $\mathrm{SHR}$ demonstrated a higher \% of MR+ cells with co-expression of GR (Fig. 1, left hand graph to image $B, S H R$ vs WKY rats, $p<0.01$ ). Likewise, a higher \% of MR+ cells colocalised with the GR protein in the CA3 region of SHR (Fig. 1, left hand graph to image $C, p<0.05$ ).

Real time PCR studies demonstrated that SHR expressed about 2.5-fold higher levels of MR mRNA in whole hippocampus compared to WKY rats $(p<0.01)$, in agreement with a previous report (7) (Figure 2A). Quantitative analysis of the MR immunoreactive protein in the CA1 and CA3 regions showed larger total immunoreactive area $/ \mathrm{mm}^{2}$ in SHR

This article is protected by copyright. All rights reserved. 
compared to WKY rats (Figures $2 \mathrm{~B}$ and $2 \mathrm{C}$; $\mathrm{p}<0.05$ for $\mathrm{CA} 1$ and $\mathrm{p}<0.05$ for $\mathrm{CA} 3$ ). In contrast, GR mRNA levels in whole hippocampus were similar in both strains (Fig.2D), although differences in GR total immunoreactive area were obtained in the CA1 region, favoring SHR over WKY rats (Fig. 2E). Thus, we observed stimulated expression of MR mRNA in whole hippocampus and of MR protein in pyramidal cell layers of SHR.

\section{Microglia morphological phenotype in SHR and WKY rats.}

We used lba1 immunofluorescence staining and confocal microscopy to compare microglia morphological phenotypes in WKY rats and SHR. Three areas of the hippocampus were selected for the study, i.e., CA1 and CA3 pyramidal regions and the hilus of the dentate gyrus. Iba1+ cells were classified into two main types using light microscopy: cells showing a highly ramified processes and small soma, and cells showing a hypertrophied soma with less pronounced processes. The last group also included cells with ameboid-like appearance, but was present in very minor amounts. The top images of Figure 3 shows examples of the ramified (a), hypertrophic (b) and ameboid (c) lba1+ cells used for morphological classification. Differences in cell types in the mentioned regions of WKY rats and SHR were analysed by Student's "t". As shown in the graphs below the images of Figure 3 , SHR showed higher number of ramified microglia in the CA1 region (left hand histogram; $p<0.05$ vs WKY), in the CA3 region (center histogram; $p<0.05$ vs WKY) as well as in the hilus (right hand histogram; $p<0.05$ ). Further analysis of microglia phenotypes by ANOVA followed by a post-hoc test demonstrated that hypertrophic microglia outnumbered the ramified form in WKY rats (CA1; NS; CA3 $p<0.01$; hilus $p<0.001)$. However, a different morphological profile was found for SHR, because in this strain ramified and hypertrophic microglia were equally distributed for all regions of the hippocampus ( $p: N S$ ).

Because morphology by itself may not be the only criterion to discriminate quiescent from activated microglia, we next analysed the expression of proinflammatory and antiinflammatory mediators. This procedure would better establish the ubiquitous immunophenotype of glial cells in SHR and WKY rats.

\section{3) Comparative expression of a marker of MR/GR activation and proinflammatory and anti-inflammatory factors in the hippocampus of SHR and WKY rats.}

To investigate if changes of microglia phenotype were accompanied by markers of neuroinflammation, we measured by qPCR several molecules bound to inflammation and signalling in the hippocampus of the two strains. First, we determined SGK1, a determinant 
of mineralocorticoid and glucocorticoid function (24) that fosters inflammation in the periphery (34). In consonance with these effects, the hippocampus of SHR showed a 5-fold increase in Sgk1 mRNA, compared to WKY rats ( $p<0.01$, Fig. 4A). We also determined Cox2, an enzyme associated with vascular inflammation in SHR (35). Cox2 mRNA was increased 2-fold in the hippocampus of SHR vs WKY rats (Fig. 4B, p<0.05). Third, the mRNA for the inflammasome component NIrp3 was higher in SHR vs WKY rats (Fig. $4 \mathrm{C}$, $\mathrm{p}<0.05)$. However, the cytokine Tnf $\alpha$ mRNA in SHR was not significantly different compared to WKY rats (Fig.4D). In contrast to the high expression of the proinflammatory mediators Sgk1, Cox2 and NIrp3 mRNAs, levels of the anti-inflammatory molecule Tgf $\beta$ was reduced in SHR vs. WKY rats (Fig. 4E; $p<0.05$ ). Finally, in consonance with findings in the brain of SHR (36), the NADPH-diaphorase activity of NOS was significantly lower in the hippocampus CA1 area of SHR vs. WKY rats (Fig. 4F). Therefore, changes of a MR-responsive gene, pro and anti-inflammatory cytokines and the NADPH-diaphorase activity of NOS evolved concomitantly with MR and possibly GR overdrive in the hippocampus of SHR.

\section{DISCUSSION}

The present study demonstrated further differences in the hippocampus of SHR, suggesting a link between increased MR expression and neuroinflammation in this hypertensive strain.

The current data demonstrate that increased hippocampal MR expression is associated with a shift in balance towards increased expression of pro-inflammatory genes at the expense of anti-inflammatory factors. The results concerning MR agree with higher binding and expression of MR in the hippocampus and heart, kidney and endothelial vasculature of SHR vs. WKY rats $(3,4,7,9,10)$. In the SHR hippocampus, higher MR expression may be related to existing neuropathology, a circumstance which unmasks this receptor as a proverbial "death receptor" under adverse conditions. It is thought that MR activation mediates a switch from vascular health to damage, inflammation and fibrosis in response to cardiovascular risk factors (37-39). Regarding the GR, qPCR did not show strain differences in mRNA levels, but the total immunoreactive GR protein was significantly elevated in SHR vs. WKY rats. However, it should be considered that qPCR data was obtained from whole hippocampus, containing regions of high (CA1, CA3 and dentate gyrus) and of low GR expression (CA3). Instead, immunostaining of Fig.2E corresponds to the CA1 region which shows high GR expression. Immunofluorescence staining revealed further strain differences in receptor localization. Whereas MR localized mainly in the cell nuclei, GR

This article is protected by copyright. All rights reserved. 
labelling was also found in cytoplasm and cell processes. These differences depend on the receptor in question, because GR becomes visible as a function of corticosterone concentration which concentrates the signal in the nucleus. The MR does not have that problem because due to its high affinity it is occupied throughout the day (23). In both cases, higher intensity staining for MR and GR was observed for SHR versus WKY rats. These changes suggest that differences may exist in the mechanism of steroid action in the hippocampus of hypertensive rats, the nature of which awaits further elucidation.

Factors implicated in MR overdrive may comprise oxidative stress; the novel MR activators small GTP (guanosine triphosphate)-binding protein Rac1 and adipocytederived aldosterone-releasing factor (ARF), the renin-angiotensin system and corticotrophinreleasing factor (40-42). Oxidative stress may play an important role, because it seems to boost the activation of MR by endogenous glucocorticoids $(38,39,43)$. It is thought to be a direct consequence of an intracellular redox change and/or absence of the enzyme $11 \beta$ hydroxysteroid dehydrogenase type 2 in hippocampus (44). This enzyme protects normally the aldosterone-selective MR in kidney, vascular endothelial cells and in discrete brain regions $(45,46)$. This condition of elevated $M R$ in the face of risk factors may increase hippocampal vulnerability, as shown by the profound neuropathology found in SHR $(1,2,7,12,16,47,48)$.

In the hippocampus, the preferred MR ligand is corticosterone and not aldosterone, due to the absence of 11-HSD2; corticosterone binds with high affinity to MR and $\sim 10$ fold lower affinity to the GR (23). MR and GR are co-expressed in hippocampal neurons (see Figure 2) $(31,49)$ and bind for the same glucocorticoid response elements (GRE) in the hippocampal genome as homo- and heterodimers (50-52). Although under certain conditions corticosterone enhances hippocampal inflammation $(53,54)$, the extent to which GR also played a damaging role in the hippocampus of SHR remains to be established. In the current study the variation in GR immunoreactivity in the nucleus needs to be considered with caution because of uncertainty about the circulating levels corticosterone (55). Nevertheless, corticosterone may be the prevalent steroid binding in SHR brain, because serum aldosterone is 9-fold lower in SHR $(33.8 \pm 12.9 \mathrm{pg} / \mathrm{ml})$ compared to WKY rats $(295 \pm$ $94.5 \mathrm{pg} / \mathrm{ml})(7)$.

Enhanced co-expression of MR and GR in neurons in the hippocampus of SHR was detected by dual immunofluorescence analysis and confocal microscopy. In our studies, a strong response of the MR and GR target gene Sgk1 was found in SHR hippocampus . Although we did not localise the cellular type responsible for the increased Sgk1 mRNA, the kinase has been detected in neurons, oligodendrocytes, astrocytes and microglia (56). Lang

This article is protected by copyright. All rights reserved. 
et al.have shown that MR activation stimulates expression of SGK1 in neurons (57). Therefore, up-regulation of Sgk1 in the hippocampus of SHR indicates that MR and GR are functionally active and may be involved in neuroinflammation. Proof of receptor activation is the increase of Sgk1 expression, a molecule genomically regulated by mineralocorticoids and glucocorticoids and involved in MR-mediated inflammation (34). However, SGK1 plays other roles than inflammation, because it is also implicated in the physiology and pathophysiology of sodium transport (34). This property opens additional possibilities for the role of SGK1 in the hippocampus.

The high expression levels of MR mRNA and protein support MR-sensitive inflammation in the hippocampus of SHR. Previous reports have suggested that imbalance in MR:GR stimulation increases hippocampal vulnerability and worsens inflammation $(54,58,59)$. In SHR, this possibility is supported by analysis of proinflammatory and antiinflammatory factors. The inducible COX isoform (COX2) produces prostanoids related to the pathogenesis of hypertension, microglia activation and neuroinflammation in DOCA-salt hypertensive rats (60), a model sharing strong similarities with SHR (2); COX2 protein levels are elevated in the urine and kidney of SHR (61), supporting a role for COX2 in the pathophysiology of hypertension. In addition, SHR also showed increased hippocampal expression of NIrp3 subunit of the inflammasome, localised in neurons and microglia (62) and astrocytes following inflammation (63). Relevant to our results, is that the NLRP3 inflammasome is involved in the vascular effects of aldosterone and is increased in hypertensive patients (64).

In contrast with the increased expression of Cox2 and NIrp3 mRNAs in SHR versus WKY rats, expression of $\operatorname{Tgf} \beta 1$ and NADPH-diaphorase activity were reduced and TNF $\alpha$ was unmodified. Acting on microglia, Tgf $\beta 1$ reduces the production of reactive oxygen species and proinflammatory factors (25) However, even if changes of TGF $\beta 1$ protein accompanies changes of TGF $\beta 1$ expression, this will not give final proof for an antiinflammatory role of this factor in SHR. Regarding the decreased NADPH-diaphorase activity, it possibly depends on an enhanced MR activation (26). In support of our findings, low NOS expression has been already reported in the SHR hippocampus (13),suggesting impaired vasodilation. In spite of the fact that $\mathrm{TNF}_{\alpha}$ is an important proinflammatory cytokine, its mRNA levels were not significantly different between SHR and WKY rats. It has been reported that TNF $\alpha$ involvement is involved hypertensive vascular remodelling (65) in brain regions outside the hippocampus; Tayebati et al. (15) reported increased immunoreactive TNF $\alpha$ in frontal cortex but not hippocampus in 8 week old SHR vs. WKY 
rats. The unchanged levels of TNFa shown by Tayebati et al (15) and our own study in the hippocampus, suggest a moderate pro-inflammatory environment of this brain region in SHR . In summary, the MR-induced damage to the hippocampus of SHR appears to be mediated by enhanced expression of some, but not all, proinflammatory mediators and by decreased expression of vasodilators and putative anti-inflammatory mediators.

On the basis of these results, we propose that in the hippocampus of SHR, MR activation may drive a vicious circle starting with the deleterious effects of hypertension on the vasculature (37). The latter causes hypoxic neuronal damage, followed by microgliosis and astrogliosis, a process promoted via MR (66). Reactive glial cells respond by producing some proinflammatory factors and decreasing anti-inflammatory TGF $\beta$ and NOS, processes that exacerbate oxidative stress and neuroinflammation. In addition, increased MR transcription and translation may promote hippocampal glutamate release leading eventually to excitotoxicity (67-69). Hence MR is changed into a damaging receptor which fosters neuroinflammation and oxidative stress. In addition, the colocalisation of MR / GR in hippocampus of SHR may signal receptor cooperativity at the Sgk1 gene, as postulated for MR:GR heterodimers in the hippocampus of stressed rats by Mifsud and Reul (51). Given our results, it is possible that increased MR expression and enhanced MR/GR colocalisation in pyramidal neurons is relevant to the risk of hippocampal abnormalities.

Our findings raise a number of questions. First, does higher MR expression cause the increase in pro-inflammatory markers in hippocampus? To address this question the increase in MR needs to be generalised to glial and vascular endothelial cells in the SHR and show colocalisation with the increased expression of pro-inflammatory genes. Second, does the hippocampal MR pro-inflammatory phenotype translate in altered behaviour of the SHR rat? It is of relevance here that SHR rats are a classical model to study attention deficit hyperactivity disorder $(70,71)$ and show a different coping style compared with WKY controls (72). Third, how is the increase in ramified microglia related to the increased expression of pro-inflammatory markers?. Further analysis of data from Figure 3 indicates that WKY rats showed more hypertrophic than ramified Iba1+ cells, whereas SHR showed similar numbers of the ramified and hypertrophic phenotype in the CA1, CA3 and hilus. In this regard, microglia heterogeneity occurs in neurodegenerative diseases (30). We would like to propose, based on literature information, that the microglia phenotype of SHR is consistent with a condition of chronic, subtle inflammation as reported in major neurodegenerative diseases including Alzheimer's disease (73). In this regard, neurodegenerative changes in the brain of SHR have been demonstrated by several laboratories. $(12,14,16,47)$. Then, it

This article is protected by copyright. All rights reserved. 
is possible, although not yet proven, that the morphological changes of microglia in SHR hippocampus may be secondary to adrenal receptor imbalance and oxidative stress.

In conclusion, we have shown in the hippocampus of SHR higher expression of MR and more immunoreactive MR and GR positive cells which results in a bias towards a proinflammatory phenotype characteristic for hypertensive encephalopathy. Thus, current evidence suggests that the MR becomes activated under adverse conditions via an altered intracellular redox mechanism (38). This increased MR activity promotes priming and activation of microglia in the neurovascular niche of hippocampus, as shown by morphology and Iba1 immunohistochemistry. This condition can be mimicked by excess deoxycorticosterone in the DOCA salt treated animal model (2). Further work will further define the role of the endothelial and neuronal MR in the context of neuroinflammation and cardiovascular risk factors (37).

\section{ACKNOWLEDGEMENTS}

This work was supported by the Ministry of Science and Technology (grants PICT 2012-0009 and PICT 2012-0820), the National Research Council of Argentina (grant PIP 112 20120100016), the University of Buenos Aires (grant Ubacyt 20020130100418BA) and Roemmers and Baron Foundations. These funding sources did not have a role in the collection, analysis, and interpretation of data; in the writing of the report; and in the decision to submit the paper for publication. The authors report no conflict of interests.

This article is protected by copyright. All rights reserved. 


\section{REFERENCES}

1 Pietranera L, Saravia F, Roig P, Lima A, De Nicola AF. Mineralocorticoid treatment upregulates the hypothalamic vasopressinergic system of spontaneously hypertensive rats. Neuroendocrinology 2004; 80: 100-110.

2 Pietranera L, Saravia F, Gonzalez Deniselle MC, Roig P, Lima A, De Nicola AF. Abnormalities of the hippocampus are similar in deoxycorticosterone acetate-salt hypertensive rats and spontaneously hypertensive rats. J Neuroendocrinol 2006; 18 : 466-474.

3 Koch B, Sakly M, Lutz-Bucher B. Specific mineralocorticoid receptors in the hippocampus of spontaneously hypertensive $(\mathrm{SH})$ rats. I. Evidence for a sex difference. Horm Metab Res 1982; 14: 166.

4 Sutanto W, Oitzl MS, Rots NY, Schöbitz B, Van den Berg DT, Van Dijken HH et al. Corticosteroid receptor plasticity in the central nervous system of various rat models. Endocr Regul 1992; 26: 111-118.

5 Saavedra JM. Brain angiotensin II: new developments, unanswered questions and therapeutic opportunities. Cell Mol Neurobiol 2005; 25: 485-512.

6 Djordjevic J, Vuckovic T, Jasnic N, Cvijic G. Effect of various stressors on the blood ACTH and corticosterone concentration in normotensive Wistar and spontaneously hypertensive Wistar-Kyoto rats. Gen Comp Endocrinol 2007; 153: 217-220.

7 Pietranera L, Brocca ME, Cymeryng C, Gomez-Sanchez E, Gomez-Sanchez CE, Roig P et al. Increased expression of the mineralocorticoid receptor in the brain of spontaneously hypertensive rats. J Neuroendocrinol 2012; 24: 1249-1258.

8 Nakano M, Hirooka Y, Matsukawa R, Ito K, Sunagawa K. Mineralocorticoid receptors/epithelial $\mathrm{Na}(+)$ channels in the choroid plexus are involved in hypertensive mechanisms in stroke-prone spontaneously hypertensive rats. Hypertens Res 2013; 36: 277-284.

9 Mirshahi M, Nicolas C, Agarwal MK. Enhanced activation of the mineralocorticoid receptor in genetically hypertensive rats. Biochem Biophys Res Commun 1998; 244: $120-125$.

10 DeLano FA, Schmid-Schönbein GW. Enhancement of glucocorticoid and mineralocorticoid receptor density in the microcirculation of the spontaneously hypertensive rat. Microcirculation 2004; 11: 69-78.

11 Rahmouni K, Barthelmebs M, Grima M, Imbs JL, De Jong W. Involvement of brain mineralocorticoid receptor in salt-enhanced hypertension in spontaneously hypertensive rats. Hypertension 2001; 38: 902-906.

This article is protected by copyright. All rights reserved. 
12 Sabbatini M, Catalani A, Consoli C, Marletta N, Tomassoni D, Avola R. The hippocampus in spontaneously hypertensive rats: an animal model of vascular dementia? Mech Ageing Dev 2002; 123: 547-559.

13 Huang Y, Wu L, Xu C, Yang B, Wang R. Increased HO-1 expression and decreased iNOS expression in the hippocampus from adult spontaneously hypertensive rats. Cell Biochem Biophys 2006; 46: 35-42.

14 Lopez-Campistrous A, Hao L, Xiang W, Ton D, Semchuk P, Sander J et al. Mitochondrial dysfunction in the hypertensive rat brain: respiratory complexes exhibit assembly defects in hypertension. Hypertension 2008; 51: 412-419.

15 Tayebati SK, Tomassoni D, Amenta F. Neuroinflammatory Markers in Spontaneously Hypertensive Rat Brain: An Immunohistochemical Study. CNS Neurol Disord Drug Targets 2016; 15: 995-1000.

16 Brocca ME, Pietranera L, Beauquis J, De Nicola AF. Estradiol increases dendritic length and spine density in CA1 neurons of the hippocampus of spontaneously hypertensive rats: a Golgi impregnation study. Exp Neurol 2013; 247: 158-164.

17 Dinh QN, Young MJ, Evans MA, Drummond GR, Sobey CG, Chrissobolis S. Aldosterone-induced oxidative stress and inflammation in the brain are mediated by the endothelial cell mineralocorticoid receptor. Brain Res 2016; 1637: 146-153.

18 Tanaka J, Fujita H, Matsuda S, Toku K, Sakanaka M, Maeda N. Glucocorticoid- and mineralocorticoid receptors in microglial cells: the two receptors mediate differential effects of corticosteroids. Glia 1997; 20: 23-37.

19 Shen XZ, Li Y, Li L, Shah KH, Bernstein KE, Lyden $\mathrm{P}$ et al. Microglia participate in neurogenic regulation of hypertension. Hypertension 2015; 66: 309-316.

20 Ferguson D, Sapolsky R. Mineralocorticoid receptor overexpression differentially modulates specific phases of spatial and nonspatial memory. J Neurosci 2007; 27: 8046-8052.

21 Kanatsou S, Fearey BC, Kuil LE, Lucassen PJ, Harris AP, Seckl JR et al. Correction: Overexpression of Mineralocorticoid Receptors Partially Prevents Chronic StressInduced Reductions in Hippocampal Memory and Structural Plasticity. PloS One 2015; 10: e0145706.

22 Han F, Ozawa H, Matsuda K, Nishi M, Kawata M. Colocalization of mineralocorticoid receptor and glucocorticoid receptor in the hippocampus and hypothalamus. Neurosci Res 2005; 51: 371-381.

23 De Kloet ER. From receptor balance to rational glucocorticoid therapy. Endocrinology 2014; 155: 2754-2769.

24 Anacker C, Cattaneo A, Musaelyan K, Zunszain PA, Horowitz M, Molteni R et al. Role for the kinase SGK1 in stress, depression, and glucocorticoid effects on hippocampal neurogenesis. Proc Natl Acad Sci U S A 2013; 110: 8708-8713.

This article is protected by copyright. All rights reserved. 
25 Qian L, Wei S-J, Zhang D, Hu X, Xu Z, Wilson B et al. Potent anti-inflammatory and neuroprotective effects of TGF-beta1 are mediated through the inhibition of ERK and p47phox-Ser345 phosphorylation and translocation in microglia. J Immunol 2008; 181: 660-668.

26 Nagata D, Takahashi M, Sawai K, Tagami T, Usui T, Shimatsu A et al. Molecular mechanism of the inhibitory effect of aldosterone on endothelial NO synthase activity. Hypertension 2006; 48: 165-171.

27 Paxinos G, Watson C. The Rat Brain in Stereotaxic Coordinates. San Diego, CA, USA: Academic Press, 1997.

28 Livak KJ, Schmittgen TD. Analysis of relative gene expression data using real-time quantitative PCR and the 2(-Delta Delta C(T)) Method. Methods 2001; 25: 402-408.

29 Kirkham M, Berg DA, Simon A. Microglia activation during neuroregeneration in the adult vertebrate brain. Neurosci Lett 2011; 497: 11-16.

30 Ekdahl CT. Microglial activation - tuning and pruning adult neurogenesis. Front Pharmacol 2012; 3: 41.

31 Van Eekelen JA, De Kloet ER. Co-localization of brain corticosteroid receptors in the rat hippocampus. Prog Histochem Cytochem 1992; 26: 250-258.

32 Vincent SR, Kimura $\mathrm{H}$. Histochemical mapping of nitric oxide synthase in the rat brain. Neuroscience 1992; 46: 755-784.

33 Labombarda F, Gonzalez SL, Gonzalez DMC, Guennoun R, Schumacher M, de Nicola AF. Cellular basis for progesterone neuroprotection in the injured spinal cord. $J$ Neurotrauma 2002; 19: 343-355.

34 Artunc F, Lang F. Mineralocorticoid and SGK1-sensitive inflammation and tissue fibrosis. Nephron Physiol 2014; 128: 35-39.

35 Renna NF, Diez ER, Lembo C, Miatello RM. Role of Cox-2 in vascular inflammation: an experimental model of metabolic syndrome. Mediators Inflamm 2013; 2013: 513251.

36 Hojná S, Kuneš J, Zicha J. Alterations of NO synthase isoforms in brain and kidney of rats with genetic and salt hypertension. Physiol Res 2010; 59: 997-1009.

37 Davel AP, Anwar IJ, Jaffe IZ. The endothelial mineralocorticoid receptor: mediator of the switch from vascular health to disease. Curr Opin Nephrol Hypertens 2017; 26: 97-104. .

38 Funder JW. Aldosterone, mineralocorticoid receptors and vascular inflammation. Mol Cell Endocrinol 2004; 217: 263-269.

39 Gomez-Sanchez E, Gomez-Sanchez CE. The multifaceted mineralocorticoid receptor. Compr Physiol 2014; 4: 965-994.

This article is protected by copyright. All rights reserved. 
40 Xue B, Beltz TG, Yu Y, Guo F, Gomez-Sanchez CE, Hay M et al. Central interactions of aldosterone and angiotensin II in aldosterone- and angiotensin II-induced hypertension. Am J Physiol Heart Circ Physiol 2011; 300: H555-564.

41 Jaffe IZ, Mendelsohn ME. Angiotensin II and aldosterone regulate gene transcription via functional mineralocortocoid receptors in human coronary artery smooth muscle cells. Circ Res 2005; 96: 643-650.

42 Gesing A, Bilang-Bleuel A, Droste SK, Linthorst AC, Holsboer F, Reul JM. Psychological stress increases hippocampal mineralocorticoid receptor levels: involvement of corticotropin-releasing hormone. J Neurosci 2001; 21: 4822-4829.

43 Young MJ, Morgan J, Brolin K, Fuller PJ, Funder JW. Activation of mineralocorticoid receptors by exogenous glucocorticoids and the development of cardiovascular inflammatory responses in adrenalectomized rats. Endocrinology 2010; 151: 2622-2628.

44 Mihailidou AS, Loan Le TY, Mardini M, Funder JW. Glucocorticoids activate cardiac mineralocorticoid receptors during experimental myocardial infarction. Hypertension 2009; 54: 1306-1312.

45 Edwards CR, Stewart PM, Burt D, Brett L, Mclntyre MA, Sutanto WS et al. Localisation of 11 beta-hydroxysteroid dehydrogenase--tissue specific protector of the mineralocorticoid receptor. Lancet 1988; 2: 986-989.

46 Funder JW, Pearce PT, Smith R, Smith Al. Mineralocorticoid action: target tissue specificity is enzyme, not receptor, mediated. Science 1988; 242: 583-585.

47 Li Y, Liu J, Gao D, Wei J, Yuan H, Niu X et al. Age-related changes in hypertensive brain damage in the hippocampi of spontaneously hypertensive rats. Mol Med Rep 2016; 13: 2552-2560.

48 Pietranera L, Saravia FE, Roig P, Lima A, De Nicola AF. Protective effects of estradiol in the brain of rats with genetic or mineralocorticoid-induced hypertension. Psychoneuroendocrinology 2008; 33: 270-281.

49 Van Steensel B, van Binnendijk EP, Hornsby CD, van der Voort HT, Krozowski ZS, de Kloet ER et al. Partial colocalization of glucocorticoid and mineralocorticoid receptors in discrete compartments in nuclei of rat hippocampus neurons. J Cell Sci 1996; 109: 787792.

50 Polman JAE, de Kloet ER, Datson NA. Two populations of glucocorticoid receptorbinding sites in the male rat hippocampal genome. Endocrinology 2013; 154: 18321844.

51 Mifsud KR, Reul JMHM. Acute stress enhances heterodimerization and binding of corticosteroid receptors at glucocorticoid target genes in the hippocampus. Proc Natl Acad Sci U S A 2016; 113: 11336-11341.

This article is protected by copyright. All rights reserved. 
52 Trapp T, Rupprecht R, Castrén M, Reul JM, Holsboer F. Heterodimerization between mineralocorticoid and glucocorticoid receptor: a new principle of glucocorticoid action in the CNS. Neuron 1994; 13: 1457-1462.

53 Frank MG, Hershman SA, Weber MD, Watkins LR, Maier SF. Chronic exposure to exogenous glucocorticoids primes microglia to pro-inflammatory stimuli and induces NLRP3 mRNA in the hippocampus. Psychoneuroendocrinology 2014; 40: 191-200.

54 Sorrells SF, Munhoz CD, Manley NC, Yen S, Sapolsky RM. Glucocorticoids increase excitotoxic injury and inflammation in the hippocampus of adult male rats. Neuroendocrinology 2014; 100: 129-140.

55 Sarabdjitsingh RA, Meijer OC, Schaaf MJM, de Kloet ER. Subregion-specific differences in translocation patterns of mineralocorticoid and glucocorticoid receptors in rat hippocampus. Brain Res 2009; 1249: 43-53.

56 Inoue K, Sakuma E, Morimoto H, Asai H, Koide Y, Leng T et al. Serum- and glucocorticoid-inducible kinases in microglia. Biochem Biophys Res Commun 2016; 478: 53-59.

57 Lang F, Strutz-Seebohm N, Seebohm G, Lang UE. Significance of SGK1 in the regulation of neuronal function. J Physiol 2010; 588: 3349-3354.

58 De Kloet ER, Joëls M, Holsboer F. Stress and the brain: from adaptation to disease. Nat Rev Neurosci 2005; 6: 463-475.

59 Sasaki K, Yoshizaki F. Investigation into hippocampal nerve cell damage through the mineralocorticoid receptor in mice. Mol Med Rep 2015; 12: 7211-7220.

60 Sriramula S, Xia H, Xu P, Lazartigues E. Brain-targeted angiotensin-converting enzyme 2 overexpression attenuates neurogenic hypertension by inhibiting cyclooxygenasemediated inflammation. Hypertension 2015; 65: 577-586.

61 Elmarakby AA, Faulkner J, Posey SP, Sullivan JC. Induction of hemeoxygenase-1 attenuates the hypertension and renal inflammation in spontaneously hypertensive rats. Pharmacol Res 2010; 62: 400-407.

62 De Rivero Vaccari JP, Dietrich WD, Keane RW. Activation and regulation of cellular inflammasomes: gaps in our knowledge for central nervous system injury. J Cereb Blood Flow Metab 2014; 34: 369-375.

63 Slowik A, Beyer C. Inflammasomes are neuroprotective targets for sex steroids. J Steroid Biochem Mol Biol 2015; 153: 135-143.

64 Bruder-Nascimento T, Ferreira NS, Zanotto CZ, Ramalho F, Pequeno IO, Olivon VC et al. NLRP3 Inflammasome Mediates Aldosterone-Induced Vascular Damage. Circulation 2016; 134: 1866-1880.

This article is protected by copyright. All rights reserved. 
65 Pires PW, Girgla SS, Moreno G, McClain JL, Dorrance AM. Tumor necrosis factor-a inhibition attenuates middle cerebral artery remodeling but increases cerebral ischemic damage in hypertensive rats. Am J Physiol Heart Circ Physiol 2014; 307: H658-669.

66 Sierra A, Gottfried-Blackmore A, Milner TA, McEwen BS, Bulloch K. Steroid hormone receptor expression and function in microglia. Glia 2008; 56: 659-674.

67 Karst H, Berger S, Turiault M, Tronche F, Schütz G, Joëls M. Mineralocorticoid receptors are indispensable for nongenomic modulation of hippocampal glutamate transmission by corticosterone. Proc Natl Acad Sci U S A 2005; 102: 19204-19207.

68 Joëls $M$, Karst $H$, DeRijk R, de Kloet ER. The coming out of the brain mineralocorticoid receptor. Trends Neurosci 2008; 31: 1-7.

69 Nasca C, Bigio B, Zelli D, Nicoletti F, McEwen BS. Mind the gap: glucocorticoids modulate hippocampal glutamate tone underlying individual differences in stress susceptibility. Mol Psychiatry 2015; 20: 755-763.

70 Sterley T-L, Howells FM, Russell VA. Genetically determined differences in noradrenergic function: The spontaneously hypertensive rat model. Brain Res 2016; 1641: 291-305.

71 Huang S-M, Wu Y-L, Peng S-L, Peng H-H, Huang T-Y, Ho K-C et al. Inter-strain differences in default mode network: A resting state $\mathrm{fMRI}$ study on spontaneously hypertensive rat and Wistar Kyoto rat. Sci Rep 2016; 6: 21697.

72 Gómez F, Lahmame A, de Kloet ER, Armario A. Hypothalamic-pituitary-adrenal response to chronic stress in five inbred rat strains: differential responses are mainly located at the adrenocortical level. Neuroendocrinology 1996; 63: 327-337.

73. Streit WJ, Xue Q-S, Tischer J, Bechmann I. Microglial pathology. Acta Neuropathol. Commun. 2014; 2:142.

\section{FIGURE LEGENDS}

Figure 1: A: Dual immunofluorescence (IF) labeling for MR (green), GR (red) and the merge (rigth hand image) in dorsal hippocampus from WKY rats and SHR. A Low power microscopy showed stronger signal for single MR staining (green) and single GR staining (red) and the merged (MR/GR, yellow) for SHR compared to WKY rats. Inside bar: $600 \mu \mathrm{m}$. B: Dual immunofluorescence stainining for MR (green), GR (red) and the merged (MR/GR, yellow) in the CA1 region and the CA3 region (C). High magnification showed that MR+ cells were more abundant in the CA1 and CA3 regions of SHR vs. the WKY group. Additionally, the merged images showed that more MR+ cells co-expressed GR in the CA1 and CA3 regions of SHR compared to WKY rats. Quantitative analysis of IF showed in the SHR group

This article is protected by copyright. All rights reserved. 
higher \% of MR+ cells with co-expression of GR compared to WKY rats in the CA1 region (rigth hand graph to $B ;{ }^{* *} \mathrm{p}<0.01$ ) and also in the $\mathrm{CA} 3$ region ( rigth hand graph to $\mathrm{C}$; * $p<0.05)$. bars : $25 \mu \mathrm{m}$.

Figure 2: Expression of MR and GR mRNA and immunoreactive protein in the hippocampus of SHR and WKY rats. MR mRNA was increased in whole hippocampus of SHR compared to $W K Y$ rats $\left(A,{ }^{* *} p<0.01\right)$. Immunostaining for $M R$ protein in the $C A 1$ region $\left(B,{ }^{*} p<0.05\right)$ and $C A 3$ region $\left(C ;{ }^{*} p<0.05\right)$ of the hypertensive rats was higher than in the normotensive strain. D: GR mRNA was similar in both strains whereas GR total immunoreactive area (E) was higher in SHR ( ${ }^{*}<<0.05$ vs WKY rats). Statistical analysis by Student's " $t$ " test.

Figure 3: Immunophenotype of microglia revealed by lba1 staining in the hippocampus of hypertensive and normotensive rats. The upper microphotographic images show examples of microglial immunophenotypes found in the CA1 hippocampal region: a) ramified type with abundant processes ; b) hypertrophic type with round soma and shorter processes.and c) ameboid. Inside bar : $20 \mu \mathrm{m}$. Quantitative analysis by Student's "t" tests showed that the ramified type prevailed in the CA1 region $\left({ }^{*} p<0.05\right)$, CA3 region $\left({ }^{*} p<0.05\right)$ and the hilus of the dentate gyrus $\left({ }^{*} p<0.05\right)$ of SHR compared to WKY rats.

Figure 4: Quantitatve analysis of responsive genes and pro and anti-inflammatory mediators by real time PCR. The graphs represent SGK1 (A), COX2 (B), NLRP3 subunit of the inflammasome (C), TNFa (D), TGF $\beta$ (E) and NADPH-diaphorase activity of nitric oxide synthase (F). SHR showed higher expression of mRNAs of genes linked to neuroinflammation $\left(A{ }^{* *} p<0.01\right),\left(B{ }^{*} p<0.05\right),\left(C{ }^{*} p<0.05\right)$, decreased transcription of the anti-inflammatory factor TGF $\left(E{ }^{*} \mathrm{p}<0.05\right)$ and decreased NADPH-diaphorase activity $(F$ $\left.{ }^{*} \mathrm{p}<0.05\right)$ compared to WKY normotensive rats. The slight increment of TNFa in SHR was not significant. Statistical analysis by Student's "t" test.

This article is protected by copyright. All rights reserved. 
Table 1 List of antibodies used for immunohistochemistry and immunofluorescence

\begin{tabular}{|c|c|c|c|c|}
\hline Antibody & Host & Trademarks & AB No. & $\begin{array}{l}\text { Working } \\
\text { dilution }\end{array}$ \\
\hline Anti-MR & Mouse & Gomez Sanchez et al (2006). & \# 365 4D6 & $1 / 400$ \\
\hline Anti-GR & Rabbit & $\begin{array}{l}\text { Santa Cruz Biotechnology, Sta. Cruz, CA, } \\
\text { USA }\end{array}$ & $\begin{array}{l}\# M-20 \\
\text { SC1004 }\end{array}$ & $1 / 200$ \\
\hline Anti-lba1 & Rabbit & Wako, Japan & \#019-19741 & $1 / 2000$ \\
\hline Anti-mouse biotinylated & Horse & $\begin{array}{l}\text { Vector Laboratories, Burlingame, CA, } \\
\text { USA }\end{array}$ & \#BA2000 & $1 / 200$ \\
\hline Anti-rabbit biotinylated & Goat & $\begin{array}{l}\text { Vector Laboratories, Burlingame, CA, } \\
\text { USA }\end{array}$ & \#BA1000 & $1 / 200$ \\
\hline $\begin{array}{l}\text { Anti-mouse IgG - Alexa Fluor } \\
488\end{array}$ & Goat & $\begin{array}{l}\text { Invitrogen - Thermo Fisher Scientific } \\
\text { Carlsbad, CA, USA }\end{array}$ & \#A11001 & $1 / 1000$ \\
\hline $\begin{array}{l}\text { Anti-rabbit lgG - Alexa Fluor } \\
555\end{array}$ & Goat & $\begin{array}{l}\text { Invitrogen - Thermo Fisher Scientific } \\
\text { Carlsbad, CA, USA }\end{array}$ & \# A-21428 & $1 / 1000$ \\
\hline
\end{tabular}

This article is protected by copyright. All rights reserved. 
Table 2_Primer sequences for real-time PCR

\begin{tabular}{|c|c|c|c|c|c|c|}
\hline Gene & $\begin{array}{c}\text { Blast } \\
\text { accession } \\
\text { number. }\end{array}$ & Forward primer 5'-3' & Reverse primer 5'-3' & $\begin{array}{c}\text { Primer } \\
\text { concentratio } \\
n\end{array}$ & cDNA & $\begin{array}{l}\text { Running } \\
\text { conditions }\end{array}$ \\
\hline MR & NM_013131 & CCAAAGGCTACCACAGTCTC & TCCCAGACCGACTATTGTCT & $0.4 \mu \mathrm{M}$ & $3 \mathrm{ng}$ & I \\
\hline GR & M14053 & $\begin{array}{l}\text { AGGCAGTGTGAAATTGTATCC } \\
\text { CAC }\end{array}$ & $\begin{array}{l}\text { GAGGCTTACAATCCTCATTCG } \\
\text { GTGT }\end{array}$ & $0.4 \mu \mathrm{M}$ & $65 \mathrm{ng}$ & II \\
\hline SGK1 & L01624 & $\begin{array}{l}\text { AATGTGCCTTTTCTGAGATTGT } \\
\text { GTT }\end{array}$ & $\begin{array}{l}\text { CACTAACTGCACACATGGGAA } \\
\text { ATAC }\end{array}$ & $0.4 \mu \mathrm{M}$ & $10 \mathrm{ng}$ & I \\
\hline $\operatorname{cox} 2$ & S67722 & $\begin{array}{l}\text { TTTGTTGAGTCATTCACCAGA } \\
\text { CAGAT }\end{array}$ & $\begin{array}{l}\text { ACGATGTGTAAGGTTTCAGGG } \\
\text { AGAAG }\end{array}$ & $0.4 \mu \mathrm{M}$ & $10 \mathrm{ng}$ & I \\
\hline NLRP3 & NM001191642 & $\begin{array}{l}\text { TCTGGTTGTGTTAATGCCTTTC } \\
\text { TTC }\end{array}$ & $\begin{array}{l}\text { GTGAATCGTCATCTCTGACTT } \\
\text { AGGA }\end{array}$ & $0.4 \mu \mathrm{M}$ & $100 \mathrm{ng}$ & 1 \\
\hline TNFa & X66539 & TCGTAGCAAACCACCAAGCA & & $0.2 \mu \mathrm{M}$ & $100 \mathrm{ng}$ & II \\
\hline
\end{tabular}

This article is protected by copyright. All rights reserved. 
GTA

TGF $\quad$ NM_021578 AGATTCAAGTCAACTGTGGAG

AAGCCCTGTATTCCGTCTC

$0.4 \mu \mathrm{M}$

$50 \mathrm{ng}$

I

Running conditions: I: optimized conditions $95^{\circ} \mathrm{C}$ at $10 \mathrm{~min}$ followed by 40 cycles at $95^{\circ} \mathrm{C}$ for $0.15 \mathrm{~s}$ and $60^{\circ} \mathrm{C}$

for $1 \mathrm{~min}$. II : $95^{\circ} \mathrm{C}$ at $10 \mathrm{~min}$ followed by 40 cycles at $95^{\circ} \mathrm{C}$ for $0.15 \mathrm{~s}, 60^{\circ} \mathrm{C}$ for $0.30 \mathrm{~s}$ and $72^{\circ} \mathrm{C}$ for $0.40 \mathrm{~s}$

This article is protected by copyright. All rights reserved. 

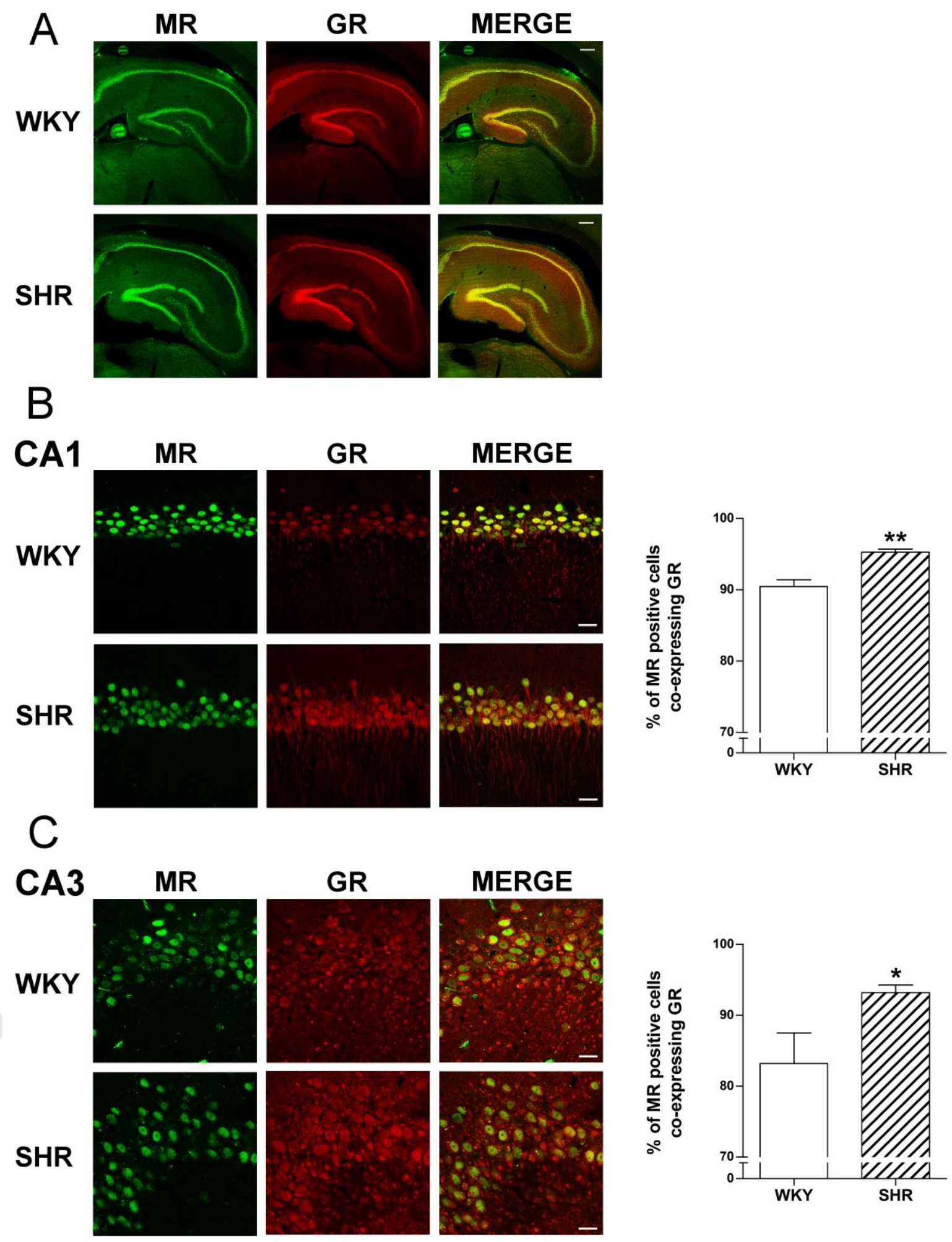

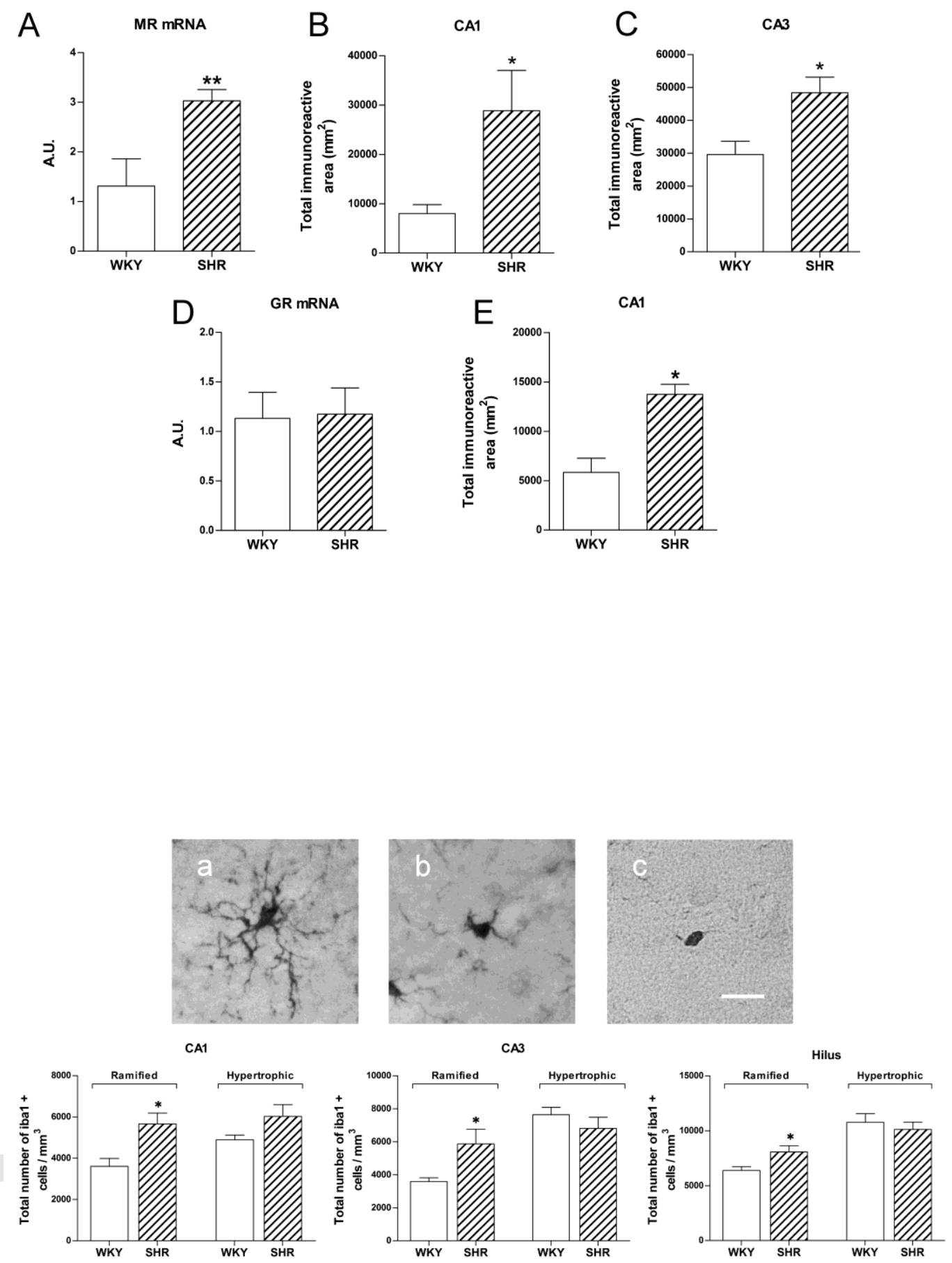

This article is protected by copyright. All rights reserved. 
A SKG1 mRNA

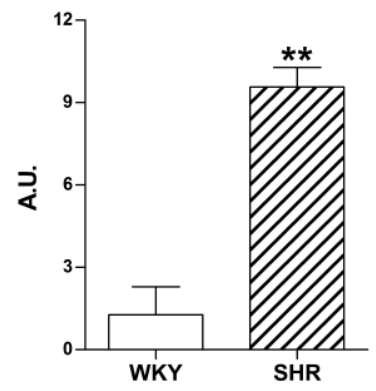

D TNF $\alpha$ mRNA

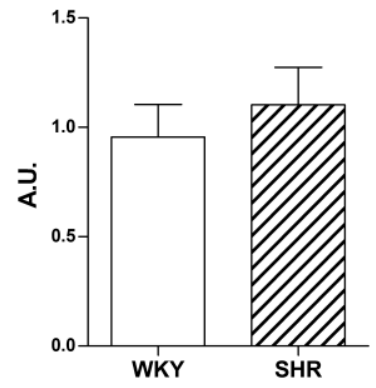

B Cox-2 mRNA

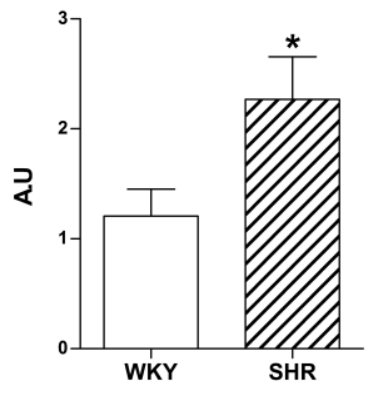

$E$

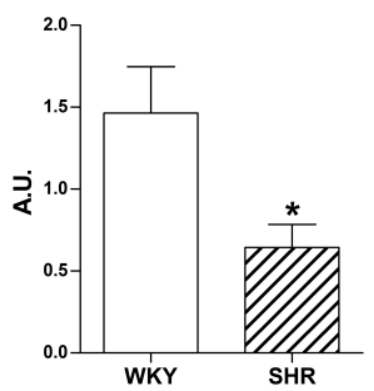

C NLRP3 mRNA

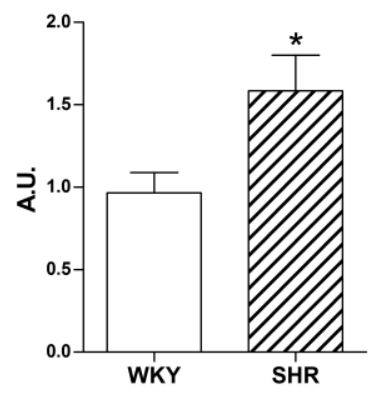

F NADPH - diaphorase

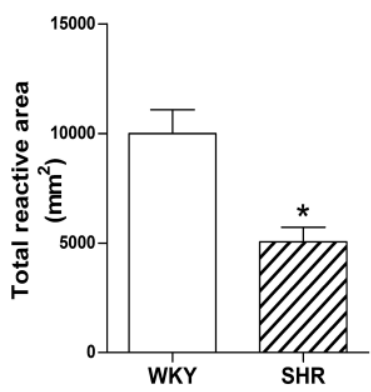

This article is protected by copyright. All rights reserved. 